\title{
Ulubey (Uşak) Beyaz Mermerlerinin Fiziko-Mekanik, Kimyasal ve Mineralojik-Petrografik Özelliklerinin Araştırılması
}

\section{Investigation of the Physico-Mechanical, Chemical and Mineralogical-Petrographic Properties of Ulubey (Usak) White Marbles}

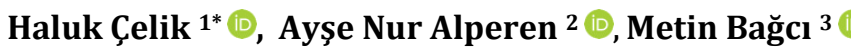 \\ 1,2 Uşak Üniversitesi Mühendislik Fakültesi Maden Mühendisliği Bölümü, Uşak, TÜRKIYE \\ ${ }^{3}$ Afyon Kocatepe Üniversitesi Mühendislik Fakültesi Jeoloji Mühendisliği Bölümü, Afyonkarahisar, TÜRKIYE \\ Sorumlu Yazar / Corresponding Author*: haluk.celik@usak.edu.tr \\ Geliş Tarihi / Received: 11.02.2021 Araştırma Makalesi/Research Article \\ Kabul Tarihi / Accepted: 19.04.2021 DOI:10.21205/deufmd.2021236913 \\ Atıfșekli/How to cite:C,ELIK H., ALPEREN A. N., BAĞCI M.(2021). Ulubey (Uşak) Beyaz Mermerlerinin Fiziko-Mekanik, Kimyasal ve \\ Mineralojik-Petrografik Özelliklerinin Araştırılması. DEÜFMD 23(69), 857-866.
}

$\ddot{0} \mathbf{z}$

Menderes Masifinde yer alan Uşak bölgesi önemli mermer potansiyeline sahiptir. Mermerlerin kullanım yerlerini belirlemede ve kullanım yerine uygun olup olmadıklarını saptamada standartlar etkin rol oynamaktadır. Bu çalıșmada, Ulubey (Uşak) bölgesindeki mermerlerinin fiziko-mekanik, kimyasal, mineralojik-petrografik özelliklerini araştırmak maksadıyla yörede bulunan farklı mermer ocaklarından örnekler alınmıştır. Örnekler mermer kesme atölyesinde TSE standartlarına uygun olarak hazırlandıktan sonra mermerlerin sahip olduğu özellikler yine standartlara uygun biçimde saptanmıștır. Belirlenen bu özellikler TS 1910, TS 2513 ve TS 10449 standart değerleri ile karşılaştırılarak doğal yapı taşı olarak kullanılma durumları belirlenmiştir. Her üç sahadan alınan numunelerin fizikomekanik özelliklerinin bu çalışmada karşılaştırması yapılan üç standartta belirtilen sınır değerleri doluluk oranı hariç sağladığı belirlenmiștir. TS 10449 standardına göre doluluk oranı minimum \%98 olmalıdır. Çalışma bölgesinde yer alan mermerlerin doluluk oranı değeri ise \%93,40-98,35 arasında olduğu hesaplanmıștır. Ulubey Beyaz mermerlerinde yapılan mineralojikpetrografik incelemelere göre mermerlerin granoblastik doku gösteren iyi gelişmiş polisentetik ikizlenmeye sahip kalsit minerallerinden oluştuğu belirlenmiștir. Kalsit minerallerinde yapılan tane boyut ölçümlerine göre tane boyutlarının 147,7 $\mu \mathrm{m}$ ile $3150 \mu \mathrm{m}$ arasında değiștiği görülmüștür.

Anahtar Kelimeler: Mermer, Ușak Beyazı, Fiziko-Mekanik Özellik, Yapı Taşı

\section{Abstract}

Uşak region is located in Menderes Massif where has a significant marble potential. Standards play an important role in determination of using areas of marbles and identifying their suitability in these areas. In this study, the samples are collected from different marble quarries in the region in order to determining physico-mechanical, chemical, mineralogical-petrographic properties of marbles in Ulubey (Uşak) when the samples have been prepared in marble factories with the TSE standards, properties of the marbles are also determined in accordance with the standards. These properties are compared with the standard values of TS 1910, TS 2513 and TS 10449 in order to determine their 
usage as natural building blocks. It has been determined that the physicomechanical properties of the samples are taken from each of the three fields provided the limit values specified in the three standards which are compared in this study, excluding the fullness rate. According to TS 10449 standard, the fullness rate should be at least $98 \%$. The fullness rate of the marbles in the study area has been calculated to be between $93.40-98.35 \%$. According to the mineralogical-petrographic investigations made on Ulubey White marbles, it was determined that the marbles consist of calcite minerals with well-developed polysynthetic twinning showing granoblastic texture. According to the grain size measurements made in calcite minerals, it has been observed that the grain size varies between $147.7 \mu \mathrm{m}$ and $3150 \mu \mathrm{m}$.

Keywords: Marble, Uşak White, Physico-Mechanical Property, Building Stone

\section{Giriș}

Alp-Himalaya kuşağı içerisinde yer alan Portekiz, İspanya, İtalya, Yunanistan, Türkiye, İran ve Pakistan gibi ülkelerde genel olarak karbonatlı kayaç (mermer, kireçtașı, traverten ve oniks) rezervlerinin fazla olduğu görülmektedir [1]. Ülkemizde jeolojik konumu nedeniyle doğal taş tanımına uygun çeșitli renk ve desenlerde sedimanter kireçtaşı, kristalize kireçtaşı (mermer), traverten, traverten oluşumlu kalker (oniks), kum taşı, konglomera, breş ve magmatik kökenli kayaçlar (granit, siyenit, diyabaz, diyorit, serpantin, vb.) ve volkanik kayaç grupları (ignimbirit, andezit, bazalt, vb.) bulunmaktadır. Ülkemiz doğal taş sektörü ticari olarak sürekliliğini ispat etmiș olup 250'nin üzerinde taş çeşidini piyasaya sürebilme potansiyeline sahip durumdadır. Bunların 100 kadarı dünya piyasalarında tanınmakta ve alıcı bulmaktadır. $\mathrm{Bu}$ mermerlerden bazıları șunlardır: Afyon Kaymak, Şeker, Kaplanpostu (Afyonkarahisar), Ușak Yeșil, Ușak Beyaz (Ușak), Süpren, Salome ve Bordo Grizo (Eskişehir), Elazığ Vişne, Hazar Pembe (Elazığ), Ege Bordo, Ayhan Siyah, Milas Leylak, Muğla Beyaz (Muğla), Kumru Tüyü (Balıkesir). Türkiye'nin toplam doğal taş kaynaklarının 5,1 milyar $\mathrm{m}^{3}$ (13,9 milyar ton) düzeyinde olduğu belirtilmektedir [2,3]. Dünya pazarlarında beğeni kazanabilecek nitelikte doğal taş çeşidine sahip olan Türkiye'de, rezervler Anadolu ve Trakya boyunca geniş bir bölgeye yayılmıştır. Rezervlerin bölgelere göre dağılımı, Ege Bölgesi \%32, Marmara \%26, İç Anadolu \% 11, Doğu Anadolu Güneydoğu Anadolu, Karadeniz ve Akdeniz Bölge'si \%31 şeklindedir [4].

Sektörde yaklaşık 2.500 adet ruhsatlı doğal taş ocağ ${ }_{1}$ bulunmakta olup bunların 1.500 adedi aktif olarak çalışmaktadır. Bunun yanı sıra fabrika ölçeğinde faaliyet gösteren 2.000 kadar tesis; orta ve küçük ölçekli 9.000 atölye faaliyet göstermektedir. Ülkemizde 2016 verilerine göre karbonat kökenli doğal taşların üretimi yıllık yaklaşık 17,5 milyon ton (bunun yaklașık 14 milyon tonu mermer) civarında olup taş işleme tesislerinin toplam plaka üretim kapasitesi 7 milyon $\mathrm{m}^{2}$ civarındadır $[2,4]$. Üretimin en fazla olduğu iller; Balıkesir, Afyon, Bilecik, Denizli ve Muğla'dır. Bu bölgelerdeki üretim, tüm üretimin $\%$ 65'ini oluşturmaktadır. Türkiye, 2019 yılı itibariyle 620 milyon ABD doları değerindeki mermer ve doğal taş ihracatı ile Çin, İtalya, Hindistan'ın ardından dördüncü sırayı almaktadır [4]. Ülkemizde üretilen mermer ve doğal taşlar 179 ülkeye ihraç edilmektedir. Türkiye'nin doğal taş sektöründeki ihracat kompozisyonuna baktığımızda, Çin'in \%37,3'lük pay ile ilk sırada yer aldığı görülmektedir. Mermer ve doğal taş sektörünün ulusal ekonomiye katkı bakımından diğer pek çok sektörden üstün yönü ithalata düşük bağlılığıdır. Mermer ve doğal tașın ocaktan çıkarılmasından mamul ürün hale gelmesine kadar geçen safhalarda ithal ara ürün kullanımı \%5 civarındadır $[2,4]$. Ülkemizin toplam madencilik ihracatından elde edilen gelirin yaklaşık \%40'ını doğal taş sektörü oluşturmaktadır [5].

Uşak İlinde 4 farklı çeşitte mermer yataklanması mevcuttur. İlimizde 31 adet mermer maden ruhsat sahası bulunmakta olup toplam ruhsat alanı 4330 hektardır. Ușak ilinin toplam mermer rezervinin ise $1.600 .000 \quad \mathrm{~m}^{3}$ olduğu belirtilmektedir [6]. Son yllarda mermer üretiminin arttığı Uşak yöresinde Karahallı, Sivaslı ve Ulubey ilçeleri civarında da büyük mermer rezervleri yer almaktadır. Uşak yöresinde uzun yıllardan beri mermer üretimi yapılmaktadır. Genellikle Mesozoik yaşlı karbonatlarda yer alan mermer ocakları içinde Uşak Yeșil, Uşak Beyaz ile Ușak Gri en çok tanınan mermer örnekleridir [3]. Ulubey ilçesi ve çevresinde Menderes Masifine ait birimler 
bulunmaktadır. Stratigrafik olarak en altta Menderes Masifi çekirdek serisine ait gnayslar ile örtü serisine ait şistler ve mermerler bulunmaktadır. İnceleme sahasında Neojen ve sonrasında gelişen karasal havzalarda çökelen killi, kumlu, marnlı ve kireçtaşlı birimler en genç stratigrafik birimleri olușturmaktadır. $\mathrm{Bu}$ birimlerin üzerine Kuvaterner yaşlı kayaçlar ile kum, kil ve siltlerden oluşan Alüvyon birimler gelmektedir. Uşak bölgesinde Menderes Masifi örtü şistleri içinde ve üstünde gözlenen stratigrafik seviyelerde farklı renk ve dokuya sahip mermer rezervleri bulunmaktadır. Bölgede mermerlerin yaygın olarak Permiyen yaşlı Sivaslı Formasyonu içinde yaralan Eldeniz mermer üyesinden ve Triyas yaşlı Boduşdamı Formasyonlarından üretiminin yapıldığ görülmektedir. Bu birim içerisindeki mermerler genellikle üst kısımda gri, beyaz renkte, alt kısımlarda ise mor ve yeșil renkli, ince-orta tabakalı, masif görünüşlüdür [7].

Doğal taşların kullanım yerlerini belirlemek ve kullanım yerine uygun olup olmadıklarını saptamak maksadıyla yine belirli standartlar çerçevesinde yapılan bir takım deneyler ile taşların fiziksel ve mekanik özellikleri belirlenmektedir. Standartlara uygun olan doğal taşlar ticari olarak alınıp satılabilirken, standart dışı olan doğal taşlar ise piyasadan çıkartılmakta veya yaygın kullanım olanağı bulamamaktadır. $\mathrm{Bu}$ yolla daha kaliteli ve dayanımı yüksek olan doğal taşlar renk, desen gibi benzerliklerinden dolayı standart dışı olan doğal taşlardan ayrılarak, gereksiz rekabet önlenmiș olmaktadır. Türk Standartları Enstitüsü (TSE) Türkiye'deki doğal tașlar için ABD'nin doğal taș standartlarından (ASTM) bir takım standartları uyarlayarak mevcut düzenlemeleri hayata geçirmiştir [8]. Mermerlerin belirlenen fizikomekanik özelliklerinin standartlarla karșılaștırılmasında sıklıkla kullanılmıș olan TS 1910 standardı TS EN 1469 ile, TS 2513 standardı TS EN 1467 ile ve TS 10449 standardı ise TS EN 1467, TS EN 1468, TS EN 12057 ve TS EN 12058 standartları ile değiştirilmiştir [9]. Yürürlüğü giren bu yeni standartları incelediğimizde ise yerine geçtikleri eski standartlarda olduğu gibi bu çalıșmada belirlenen fizikomekanik özelliklere ait limit değerlerine yer verilmediği görülmektedir. Ulubey mermerlerinin kullanım yerlerine dair kalite durumlarının somut olarak ortaya konulabilmesi ve karşılaştırma yapılabilmesi amacıyla bu çalıșmada tespiti yapılan fiziksel ve mekanik özellikler somut değerler içerdiğinden eski standartlar ile (TS 1910 [10], TS 2513 [11] ve TS 10449 [12]) karşılaştırması yapılmıştır.

Bu çalışmada Ușak İli Ulubey İlçesinde yer alan ve işletilmekte olan 3 adet mermer madeninden örnekler alınmış, bu örnekler TSE standartlarına uygun olarak mermer kesme atölyesinde $50 \times 50 \times 50 \mathrm{~mm}$ ve $50 \times 50 \times 300 \mathrm{~mm}$ boyutlarma getirildikten sonra fiziko-mekanik, kimyasal, mineralojik-petrografik özellikleri yine ilgili standartlara uygun olarak belirlenmiştir. Üç mermer yatağına ait sonuçların standart değerlerle (TS 1910, TS 2513 ve TS 10449) karşılaştırılmalı olarak değerlendirilmesi yapılmıștır.

\section{Materyal ve Metot}

\subsection{Materyal}

$\mathrm{Bu}$ çalıșma kapsamında kullanılan mermerler Șekil 1A, 1B ve 1C'de genel görünümleri verilen Uşak İli Ulubey İlçesinde üretim yapan 3 farklı mermer ocağından (Ms1, Mc2, Mh3) temin edilmiştir. Ocaktan alınan moloz boyutlu mermer parçalarından Uşak İlinde faaliyet göstermekte olan mermer atölyesinde fiziksel ve mekanik testler için standartlarda öngörülen ebatlarda, küp (50×50×50 mm) ve dikdörtgen prizması $(50 \times 50 \times 300 \mathrm{~mm})$ şeklinde örnekler hazırlanmıştır Şekil 1D.

\subsection{Metot}

Günümüzde doğal taşların yapıların iç ve dış döșemesinde kullanılabilmesine karar verebilmek için bir takım fiziko-mekanik parametrelerin belirlenmesi gerekir. Mermer numuneleri üzerinde gerçekleștirilen fiziksel (birim hacim kütle, tane yoğunluğu (piknometre yöntemi ile belirlenmiştir), porozite (gözeneklilik derecesi), ağırlıkça su emme tayini, sonik hız deneyi) ve mekanik deneyler (tek eksenli basınç dayanımı, nokta yük dayanımı, darbe dayanımı, eğilme dayanımı, Schmidt sertlik tayini, sürtünme sonrası așınma kaybı (Böhme)) TS 699/T1 [13], "Doğal Yapı Taşlarıİnceleme ve Laboratuvar Deney Yöntemleri" standardına göre gerçekleştirilmiștir. Her bir fiziko-mekanik özellik için 5'er adet numune üzerinde deneyler yapılmış ortalaması değerlendirmelerde kullanılmıștır. $\mathrm{Bu}$ deneylerin yanı sıra numuneler üzerinde kimyasal, mineralojik ve petrografik incelemeler yapılarak mermerlerin mineral türleri, mineral 


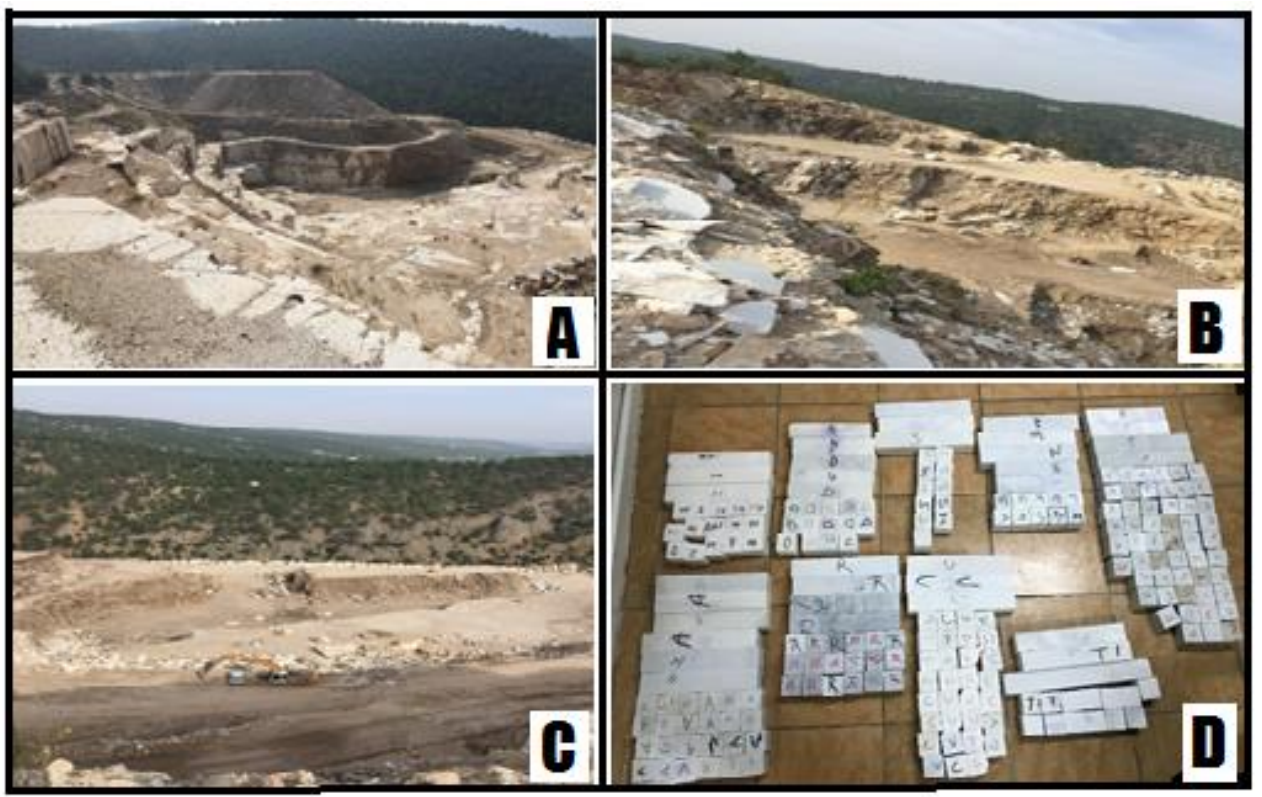

Şekil 1. Numune alınan mermer ocaklarının genel görüntüsü ve boyutlandırılmış mermer örnekleri

dağılımı, dokusal özellikleri ve kimyasal bileșimi belirlenmiştir. Fiziko-mekanik deneyler Uşak Üniversitesi Mühendislik Fakültesi laboratuvarlarında, kimyasal analizler Canakkale 18 Mart Üniversitesi Bilim ve Teknoloji Uygulama ve Araştırma Merkezinde Spectro xSort Handheld X-Ray Spektrometresi ile, mineralojik-petrografik incelemeler ise Afyon Kocatepe Üniversitesi Jeoloji Mühendisliği Bölümünde Leica Dm 2500P model polarizan mikroskop kullanılarak gerçekleştirilmiștir.

\section{Bulgular}

\subsection{Mermerlerin fiziksel özelliklerinin değerlendirilmesi}

Tablo 1.'de deneysel çalışmalarda kullanılan Uşak-Ulubey mermerlerinin belirlenen fiziksel özellikleri ve bu değerlerin standart değerler ile karşılaştırılması verilmiştir.

Mermer türüne göre birim hacim kütleleri 2,2$3,2 \mathrm{gr} / \mathrm{cm}^{3}$ arasında değişmektedir. Mermerin birim hacim kütlesinin bilinmesi özellikle yüklemelerde kullanılan sapan halatlarının kalınlıklarının ve nakliye ücretlerinin hesaplanmasında faydalıdır [14]. Ms1, Mc2 ve Mh3 mermerlerinin ortalama birim hacim kütle değerleri sırasıyla 2,$73 ; 2,75$ ve $2,74 \mathrm{gr} / \mathrm{cm}^{3}$ olarak bulunmuş olup değerler birbirine oldukça yakındır. TS 1910, TS 2513 ve TS 10449'a göre mermerlerin yapılarda kullanılabilmesi için birim hacim kütle değeri 2,55 gr/ $/ \mathrm{cm}^{3}$ değerinden büyük olmalıdır. Her üç mermer de bu limit değerini sağlamaktadır.

Ulubey mermerlerinin tane yoğunlukları piknometre yöntemi ile belirlenmiștir. Tablo 1.'den görüldüğü gibi numunelerin tane yoğunluğu değerleri 2,796-2,923 $\mathrm{gr} / \mathrm{cm}^{3}$ arasında değișmektedir.

Genellikle su emme çok ise porozite fazla, boşluk ve çatlaklar çok, ayrışma miktarı yüksek demektir. Buna karșıllık su emmenin az olması, basınç direnci, elastisite modülü gibi mekanik özelliklerin büyük olduğunu göstermektedir [15]. Çalışmalarda kullanılan mermerlerin ağırlıkça su emme oranlarının \%0,20-0,23 arasında değiștiği belirlenmiştir. Porozite oranı en fazla olan Mc2 kodlu mermerin su emme değeri de diğerlerine göre daha yüksektir. Bu değerlerin tüm ilgili TS standartlarında belirtilen sınır değerlerin altında olduğu görülmektedir.

Mermerlerde porozite oranı ne kadar büyürse ekonomik değeri o kadar azalmaktadır. İyi kalite mermerin porozitesi $\% 0,0002-0,5$ arasındadır [14]. 
DEÜ FMD 23(69), 857-866, 2021

Tablo 1. Ulubey (Uşak) beyaz mermerlerinin ortalama fiziksel özeliklerinin standartlar ile karşılaștırılması

\begin{tabular}{ccccccc}
\hline & $\begin{array}{c}\text { Birim Hacim } \\
\text { Kütlesi }\end{array}$ & $\begin{array}{c}\text { Tane } \\
\text { Yoğunluğu }\end{array}$ & $\begin{array}{c}\text { Su Emme } \\
\text { (Ağırlıça) }\end{array}$ & $\begin{array}{c}\text { Görünür } \\
\text { Porozite } \\
\text { Oranı }\end{array}$ & $\begin{array}{c}\text { Doluluk } \\
\text { Oranı }\end{array}$ & Sonik Hız \\
$\left(\mathrm{gr} / \mathrm{cm}^{3}\right)$ & $\left(\mathrm{gr} / \mathrm{cm}^{3}\right)$ & $(\%)$ & $<2$ & $(\%)$ & $(\mathrm{Km} / \mathrm{sn})$ \\
\hline TS 1910 & $>2,55$ & & $<0,75$ & & \\
\hline TS 2513 & $>2,55$ & $<1,80$ & & $>98$ & 4,18 \\
\hline TS 10449 & $>2,55$ & 2,923 & 0,21 & 0,60 & 93,40 & 4,22 \\
\hline Ms1 & 2,73 & 2,796 & 0,23 & 0,64 & 98,35 & 4,36 \\
\hline Mc2 & 2,75 & 2,840 & 0,20 & 0,59 & 96,48 & 4 \\
\hline
\end{tabular}

Tablo 1.'den görüldüğü üzere etkin (görünür) porozite değeri en düşük olan Mh3 numunesinin su emme değeri de en düşük değer olarak $(\% 0,2)$ belirlenmiștir. TS 1910'a göre kaliteli sayllabilecek bir mermerin porozitesi en fazla $\% 2$ olmalıdır. Ulubey beyaz mermerlerinin belirlenen bu porozite değerine göre standardı sağladığı görülmektedir. Moos ve Quervain (1948)'in [16] kayaçların porozite oranına göre sınıflandırma kriterlerine göre Ulubey mermerleri "Çok kompakt" kayaç sınıfına girmektedir (Tablo 2).

Tablo 2. Kayaçların porozite \% değerlerine göre sinıflandırılmaları [16]

\begin{tabular}{cc}
\hline Kayaç Sınıfı & Porozite (\%) \\
\hline Çok Kompakt & $<1$ \\
Az Boşluklu & $1-2,5$ \\
Orta Boşluklu & $2,5-5$ \\
Oldukça Boşluklu & $5-10$ \\
Çok Boşluklu & $10-20$ \\
Çok Fazla Boşluklu & $>20$ \\
\hline
\end{tabular}

Mermerlerin doluluk oranı birim hacim kütlenin özgül ağırlığa oranı olarak tanımlanmaktadır. Çalışma bölgesinde yer alan mermerlerin doluluk oranı değeri \%93,40-98,35 arasında hesaplanmıștır. TS 10449 standardına göre bu değer minimum \%98 olmalıdır. Bölge mermerlerinden doluluk oranı değerini Mc2 kodlu numune sağlarken, diğerlerinin doluluk oranları standart limitin altında olmakla birlikte bu değere oldukça yakın olduğu belirlenmiștir.

Kayaçlardaki mineralojik yapı, doku, gözeneklilik, yapıdaki mikro ve makro çatlaklar ile diğer süreksizlikler gibi fiziksel özellikler Pdalga hızlarının geçişine etki etmektedir. Yapılan deney sonucunda numunelerin P-dalga hızı 4,18$4,36 \mathrm{Km} / \mathrm{sn}$ birbirlerine oldukça yakın bulunmuş olup Tablo 3'e göre sınıflandırma yapıldığında [17] "yüksek hız" grubuna girmektedir. Genel olarak sonik dalga hızı mermerin gözeneklilik değeriyle ilişkilidir. Porozitesi düşük olan mermerlerin dalga hızı yüksek olmaktadır. Çalışmada porozite değeri en düşük olan Mh3 numunesinin sonik dalga hızı en büyük olarak $(4,36 \mathrm{Km} / \mathrm{sn})$ belirlenmiştir.

Tablo 3. Kayaçların sismik dalga hızlarına göre sınıflandırılmaları [17]

\begin{tabular}{ccc}
\hline Sınıf & $\begin{array}{c}\text { Dalga Hızı } \\
\text { (Km/sn) }\end{array}$ & Tanımlama \\
\hline 1 & $<2,5$ & Çok düşük hız \\
2 & $2,5-3,5$ & Düşük hız \\
3 & $3,5-4$ & Orta hız \\
4 & $4-5$ & Yüksek hız \\
5 & $>5$ & Çok yüksek hız \\
\hline
\end{tabular}

\subsection{Mermerlerin mekanik özelliklerinin değerlendirilmesi}

Tablo 4.'de deneysel çalıșmalarda kullanılan Uşak-Ulubey mermerlerinin belirlenen mekanik özellikleri ve bu değerlerin standart değerler ile karşılaştırılması verilmiştir.

Tek eksenli basınç dayanımı üzerine uygulanan basma yüklerine karşı kayaçların kırılmadan önce dayanma yeteneğini göstermektedir. 
DEÜ FMD 23(69), 857-866, 2021

Tablo 4. Ulubey (Ușak) beyaz mermerlerinin ortalama mekanik özeliklerinin standartlar ile karșılaștırılması

\begin{tabular}{|c|c|c|c|c|c|c|}
\hline & $\begin{array}{c}\text { Tek Eksenli } \\
\text { Basınç } \\
\text { Dayanımı } \\
\\
\left(\mathrm{kg} / \mathrm{cm}^{2}\right) \\
\end{array}$ & $\begin{array}{c}\text { Eğilme } \\
\text { Dayanımı } \\
\left(\mathrm{kg} / \mathrm{cm}^{2}\right) \\
\end{array}$ & $\begin{array}{l}\text { Darbe Direnci } \\
\left(\mathrm{Kg} . \mathrm{cm} / \mathrm{cm}^{3}\right)\end{array}$ & $\begin{array}{c}\text { Nokta Yük } \\
\text { Dayanımı } \\
\text { (Mpa) } \\
\end{array}$ & $\begin{array}{l}\text { Schmidt } \\
\text { Sertliği }\end{array}$ & $\begin{array}{c}\text { Böhme Așınma } \\
\text { Dayanımı } \\
\left(\mathrm{cm}^{3} / 50 \mathrm{~cm}^{2}\right)\end{array}$ \\
\hline TS 1910 & $>500$ & $>50$ & & & & $<15$ \\
\hline TS 2513 & $>500$ & $>50$ & $>6$ & & & $<15$ \\
\hline TS 10449 & $\begin{array}{c}>300 \\
\text { (duvar kaplama) } \\
>500 \\
\text { (yer döșeme) } \\
\end{array}$ & $>60$ & $\begin{array}{c}>4 \\
\text { (duvar kaplama) } \\
>6 \\
\text { (yer döşeme) } \\
\end{array}$ & & & $\begin{array}{c}<25 \\
\text { (duvar kaplama) } \\
<15 \\
\text { (yer döșeme) } \\
\end{array}$ \\
\hline Ms1 & 902,1 & 213,63 & 20,4 & 2,91 & 29,00 & 3,533 \\
\hline Mc2 & 923,6 & 201,86 & 16,0 & 2,83 & 26,70 & 4,400 \\
\hline Mh3 & 792,6 & 204,33 & 10,8 & 2,87 & 26,35 & 6,067 \\
\hline
\end{tabular}

Hem sınıflama hem de tasarım açısından oldukça gerekli olan mermerlerin basınç dayanımı; kristal durumu, porozite, $\mathrm{CaCO}_{3}$ miktarı ve yabancı madde içeriğine göre farklılık göstermektedir. Çalıșmanın konusu olan Ulubey (Ușak) mermerlerinin tek eksenli basınç dayanımı değeri 792,6-923,6 kg/ $\mathrm{cm}^{2}$ arasında değiștiği saptanmıștır. Belirlenen bu değerler TS 1910, TS 2513 ve TS 10449 standart değerlerinin üzerinde yer almıştır. Buna göre hem yer döșemesi, hem de duvar kaplaması olarak kullanımlarının uygun olacağ bulunmuştur. Deere ve Miller (1966) [18] tarafından önerilen kayaçların tek eksenli basınç dayanımına göre sınıflandırılması skalasınagöre, Ulubey (Uşak) beyaz mermerleri "orta dirençli" kayaç sınıfına girmektedir (Tablo 5).

Tablo 5. Kayaçların tek eksenli basınç dayanımına göre sinıflandırılması [18]

\begin{tabular}{cc}
\hline Tanım & $\begin{array}{c}\text { Basınç dayanımı } \\
\left(\mathbf{k g} / \mathbf{c m}^{2} \mathbf{)}\right.\end{array}$ \\
\hline Çok yüksek dirençli & $>2000$ \\
Yüksek dirençli & $2000-1000$ \\
Orta dirençli & $1000-500$ \\
Düşük dirençli & $500-250$ \\
Çok düşük dirençli & $<250$ \\
\hline
\end{tabular}

Doğal yapı tașları genellikle belirli boyut ve kalınlıklarda plakalar șeklinde kullanıldıklarından eğilme dirençleri önemli bir parametre olarak değerlendirmeye alınmaktadır. Numunelerin eğilmeye karşı dayanımları 201,86-213,63 $\mathrm{kg} / \mathrm{cm}^{2}$ arasında değișmekte olup Tablo 4.'den görüldüğü üzere standart değerlerin oldukça üstündedir.
Standart boyutlardaki kayac numunelerinin belirli bir doğrultuda darbelere karşı gösterdiği direnci ifade eden darbe dayanımının kayaçların kullanım alanlarının belirlenmesinde önemli bir yeri vardır. Ulubey mermerlerinin darbe dayanımı değerleri 10,8-20,4 $\mathrm{kg} . \mathrm{cm} / \mathrm{cm}^{3}$ arasında olduğu belirlenmiștir. Bu değerler TS 10449'a göre sınır değerleri (duvar kaplama için $>4 \mathrm{~kg} . \mathrm{cm} / \mathrm{cm}^{3}$, yer döşeme için $>6 \mathrm{~kg} . \mathrm{cm} / \mathrm{cm}^{3}$ ) ve TS 2513'e göre sınır değeri (>6kg.cm $/ \mathrm{cm}^{3}$ ) sağlamaktadır.

Nokta yük dayanımı deneyi kayaçların nokta yük indeksine göre sınıflandırılması veya tek eksenli basınç dayanımının tahmin edilmesi için uygulanmaktadır [19]. Deneysel çalışmalarda kullanılan üç mermerin ortalama nokta yük dayanımlarının 2,83 ile 2,91 $\mathrm{MPa}$ arasında olduğu belirlenmiş olup, Bieniawski (1975)'e [19] göre numuneler "orta dirençli" kaya sinıfında yer almaktadırlar (Tablo 6).

Tablo 6. Kayaçların nokta yük dayanımına göre sinıflandırılması [19]

\begin{tabular}{cc}
\hline Kaya Sınıfı & $\begin{array}{c}\text { Nokta Yük } \\
\text { Direnci (MPa) }\end{array}$ \\
\hline Çok Düşük Dirençli & $<1$ \\
Düşük Dirençli & $1-2$ \\
Orta Dirençli & $2-4$ \\
Yüksek Dirençli & $4-8$ \\
Çok Yüksek Dirençli & $>8$ \\
\hline
\end{tabular}

Schmidt yüzey sertlik deneyi, numunenin bütünlüğüne zarar vermeden yapılan kolay ve pratik bir deney yöntemidir. Schmidt sertlik tayini arazi ve laboratuvar ortamında kayaçların sertliklerinin belirlenmesinde ve tek eksenli 
basma dayanımlarının dolaylı yoldan tahmin edilmesinde yaygın olarak kullanılan bir test yöntemidir [20]. Yapılan çalışmada kayaçların Schmidt sertlik değerlerinin 26,35-29 arasında olduğu belirlenmiş olup, Uluslararası Kaya Mekaniği Derneği (ISRM, 1981) [21] tarafından yapılan değerlendirmeye göre Ulubey mermerlerinin "yumuşak" kayaç sınıfına girdiği belirlenmiştir (Tablo 7).

Tablo 7. Kayaçların Schmidt sertliğine göre sınıflandırılması [21]

\begin{tabular}{cc}
\hline Kaya Sınıfı & $\begin{array}{c}\text { Schmidt Yüzey } \\
\text { Sertlik Değeri }\end{array}$ \\
\hline Fevkalade Yumuşak & $16-20$ \\
Çok Yumuşak & $20-24$ \\
Yumuşak & $24-30$ \\
Sert & $30-45$ \\
Çok Sert & $45-60$ \\
Fevkalade Sert & $>60$ \\
\hline
\end{tabular}

Așınma dayanımı, așındırıcı maddeler ile mermerlerin yüzeyindeki oluşturulan aşınmaya karşı gösterdiği direnç olup, mermerlerin aşınma dayanım değerleri ne kadar düşük olursa, mermerin ekonomik değeri artmaktadır. Ulubey mermerlerinin ortalama hacimce sürtünme ile aşınma dayanımı değerlerinin 3,533 ile $6,067 \mathrm{~cm}^{3} / 50 \mathrm{~cm}^{2}$ arasında olduğu bulunmuştur. $\mathrm{Bu}$ değerler TS 10449'a göre mermerlerde sürtünmeden dolayı aşınma miktarı döșeme kaplaması, merdiven basamağı gibi yer döșemesi olarak kullanılacak mermerler için $15 \mathrm{~cm}^{3} / 50 \mathrm{~cm}^{2}$ den, duvar kaplamasında kullanilacak mermerlerde ise $25 \mathrm{~cm}^{3} / 50 \mathrm{~cm}^{2}$ den küçük olmaması gerektiği belirtilmektedir. TS 1910'a ve TS 2513'e göre sınır değer ise $<15 \mathrm{~cm}^{3} / 50 \mathrm{~cm}^{2}$ olarak belirtilmektedir. Calıșmanın konusu olan mermer numunelerinin her üç standartta verilen sürtünme ile aşınma dayanımı sınır değerlerini sağladığı belirlenmiştir.

\subsection{Mermerlerin kimyasal özellikleri}

Kimyasal bileşim kayaçların içindeki elementlerin oksit değerlerinin toplam ifadesidir. Kimyasal bileşim kayaçların fiziksel özelliklerini değiștirir. Örneğin; $\mathrm{SiO}_{2}$ oranı arttıkça kayacın sertlik değeri artarken, MgO oranı arttıkça kırılganlaşır, $\mathrm{Fe}_{2} \mathrm{O}_{3}$ oranı arttıkça ise rengi koyulaşır [22]. Tablo 8.'den görüleceği üzere mermerlerin kimyasal analiz sonuçlarına göre belirgin bir bileșim farklılığı bulunmamaktadır. Örneklerinin majör oksit değerleri incelendiğinde beklendiği gibi en yüksek değeri CaO'nun verdiği görülmektedir.
Mermerlerin kimyasal analiz sonucunda $\mathrm{CaO}$ oranlarının \%51,20-54,00 arasında olduğu, buradan hesapla \%91,43-96,43 oranında kalsit minerali $\left(\mathrm{CaCO}_{3}\right)$ içerdikleri belirlenmiștir. Ms1 numunesinin $\mathrm{CaO}$ ve $\mathrm{MgO}$ oranı diğerlerine göre azda olsa daha yüksek olduğu belirlenmiștir.

Tablo 8. Ulubey (Uşak) beyaz mermer örneklerine ait kimyasal analiz sonuçları

\begin{tabular}{cccccc}
\hline & $\mathrm{CaO}$ & $\mathrm{MgO}_{2}$ & $\mathrm{Al}_{2} \mathrm{O}_{3}$ & $\mathrm{SiO}_{2}$ & $\mathrm{TiO}_{2}$ \\
& $\mathrm{Fe}_{2} \mathrm{O}_{3}$ & $\mathrm{Cr}_{2} \mathrm{O}_{3}$ & $\mathrm{SO}_{3}$ & $\mathrm{P}_{2} \mathrm{O}_{5}$ & $\mathrm{K.K}(\%)$ \\
\hline \multirow{2}{*}{$\mathrm{Ms} 1$} & 54,00 & 2,03 & 0,15 & 0,17 & 0,061 \\
& 0,008 & 0,015 & 0,034 & 0,043 & 43,49 \\
\hline \multirow{2}{*}{$\mathrm{Mc} 2$} & 51,20 & 1,84 & 0,15 & 0,29 & 0,059 \\
& 0,015 & 0,015 & 0,200 & 0,039 & 46,18 \\
\hline \multirow{2}{*}{$\mathrm{Mh} 3$} & 51,70 & 1,65 & 0,15 & 0,58 & 0,076 \\
& 0,013 & 0,015 & 0,066 & 0,037 & 45,62 \\
\hline \multicolumn{2}{l}{ K.K: Kizdırma kaybı }
\end{tabular}

3.4 Mermerlerin mineralojik ve petrografik özellikleri

Orta-kalın katmanlı Ulubey beyaz renkli mermerler çalışma alanında geniş alanlarda yayılım sunmaktadır. Halen aktif olarak çalışan mermer ocak ișletmelerinden alınan örnekler üzerinde yapılan polarizan mikroskop incelemelerine göre Ms1 kodlu mermer örneklerinin kalsit minerallerinden oluştuğu belirlenmiştir. Kalsit tanelerinde yer yer çok düșük derecede alterasyon etkilerine rastlanılmıştır. Ayrıca örneklerde mikro çatlaklar görülmektedir. Yer yer opak minerallerin bu mikro çatlakları doldurduğu gözlenmiştir. Yapılan tane boyut ölçümlerine göre Ms1 kodlu beyaz mermerlerin tane boyutları 155,9 $\mu \mathrm{m}$ ile 2670,7 $\mu \mathrm{m}$ arasinda değişmektedir. Ms1 kodlu mermerlerin granoblastik doku gösteren iyi gelișmiș polisentetik ikizlenmeye sahip kalsit minerallerinden oluştuğu belirlenmiștir (Șekil 2 a ve b). Mc2 kodlu mermer örnekleri ise kalsit kristallerinden oluşmaktadır. Kalsit kristallerinin sınırlarının oldukça düzgün olması mermerlerin alterasyondan fazla etkilenmediğini göstermektedir. Ayrıca Mc2 kodlu mermer örneklerinde polisentetik ikizlenme çok iyi gelişmiştir. Yapılan tane boyut ölçüm değerleri 208,2 $\mu \mathrm{m}$ ile 3150,0 $\mu \mathrm{m}$ arasında değişmektedir (Şekil $2 \mathrm{c}$ ve d). Son olarak Mh3 kodlu Ulubey Beyaz renkli mermerleri de kalsit kristallerinden oluşmaktadır. Kalsit tane sınır ilişkileri incelendiğinde tane sınırlarının Mc2 kodlu örneklerde olduğu gibi tane sınırlarının oldukça düzgün olduğu görülmektedir. Mh3 kodlu mermer örneklerinde tane boyut dağılımı 


\section{DEÜ FMD 23(69), 857-866, 2021}

147,7 $\mu \mathrm{m}$ ile $1657,0 \mu \mathrm{m}$ arasında değişmektedir. Polisentetik ikizlenme Mh3 kodlu mermer örneklerinde çok iyi gelişmiş olduğu görülmektedir (Şekil 2 e ve f). Genel olarak Ulubey Beyaz renkli tüm mermer örneklerinin kalsit minerallerinden oluştuğu, polisentetik ikizlenmenin Mc2 ve Mh3 kodlu örneklerde çok iyi geliştiği görülmüştür. Ayrıca Mc2 ve Mh3 kodlu mermerlerinin alterasyondan fazla etkilenmediği ve tane sınır ilişkilerinin düzgün ve tane sınırlarının belirgin olduğu gözlenmiștir. Ayrica, Kun (2000)'e [23] göre Ulubey-Uşak mermerlerinin tane boyut dağılımları açısından Ms1 ve Mc2 "ince-orta taneli" mermer sinıfinda, Mh3 ise "ince taneli" sinıfta yer aldıkları belirlenmiştir (Tablo 9).

Tablo 9. Mermerlerin tane boyutuna göre sinıflandırılması [23]

\begin{tabular}{|c|c|c|c|}
\hline \multicolumn{2}{|c|}{$\begin{array}{l}\text { Tane Boyutu } \\
\text { Tanım Değeri }\end{array}$} & Özellikleri & Örnek \\
\hline $\begin{array}{l}\text { Çok ince } \\
\text { taneli } \\
\text { mermer }\end{array}$ & $\begin{array}{c}<100 \\
\mu \mathrm{m}\end{array}$ & $\begin{array}{l}\text { Tane boyutu } 100 \text { mikrondan küçüktür. Mermeri oluşturan taneler } \\
\text { gözle fark edilemez. Tane boyutunun çok küçük olmasından dolayı çok } \\
\text { iyi cila kabul ederler. }\end{array}$ & $\begin{array}{l}\text { Afyon } \\
\text { Mermerleri }\end{array}$ \\
\hline $\begin{array}{c}\text { İnce } \\
\text { taneli } \\
\text { mermer }\end{array}$ & $\begin{array}{c}100-2000 \\
\mu \mathrm{m}\end{array}$ & $\begin{array}{l}\text { Tane boyutu } 100 \text { mikron ile } 2000 \text { mikron }(2 \mathrm{~mm}) \text { arasında olan } \\
\text { mermerlerdir. İnce taneli mermerlerde taneler birbirine iyice } \\
\text { kenetlenmiş durumdadır. }\end{array}$ & $\begin{array}{l}\text { Muğla/Milas } \\
\text { Mermerleri } \\
\text { (Avrupa beyazı) }\end{array}$ \\
\hline $\begin{array}{l}\text { Orta } \\
\text { taneli } \\
\text { mermer }\end{array}$ & $\begin{array}{l}2-5 \\
\mathrm{~mm}\end{array}$ & $\begin{array}{l}\text { Tane boyutu } 2 \mathrm{~mm} \text { ile } 5 \mathrm{~mm} \text { arasında olan mermerlerdir. Tane } \\
\text { boyutunun büyüklügünden dolayı kesme ve partlatma işlemlerinde } \\
\text { problem meydana gelir. Genellikle kenarlardan tane düșmesi ve tane } \\
\text { kopması sonucu iyi kenar kesme özelliği vermezler. }\end{array}$ & $\begin{array}{l}\text { Bursa/Mustafa } \\
\text { Kemalpaşa } \\
\text { Beyazı }\end{array}$ \\
\hline $\begin{array}{l}\text { İri taneli } \\
\text { mermer }\end{array}$ & $\begin{array}{c}>5 \\
\mathrm{~mm}\end{array}$ & $\begin{array}{l}\text { Tane boyutu } 5 \text { mm'den daha fazla olan ve taneleri gözle görülebilen } \\
\text { mermerlerdir. Kristalleri iri olduğundan mermer dişli ve kaba } \\
\text { görünümlüdür. }\end{array}$ & Kırşehir Beyazı \\
\hline
\end{tabular}
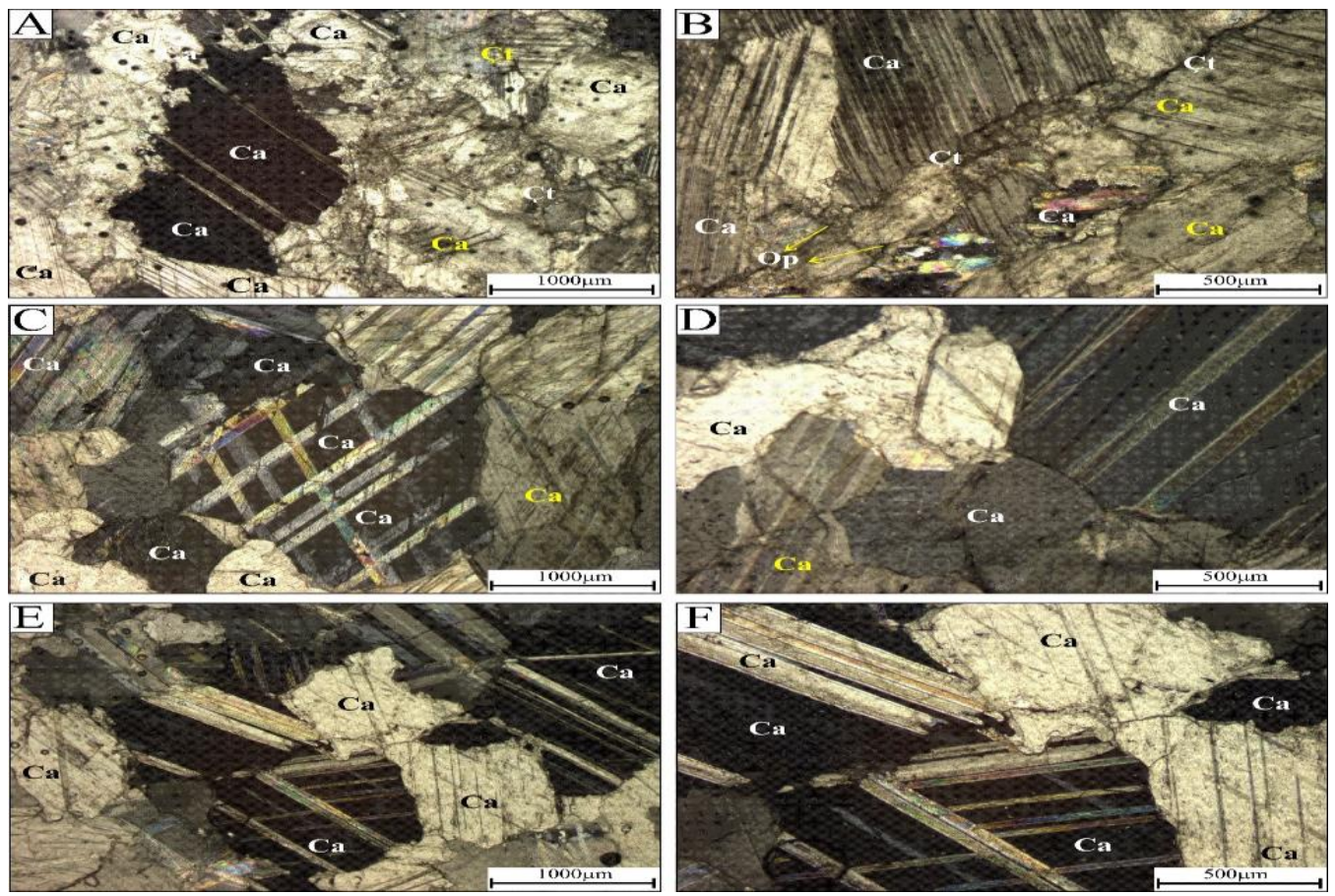

Şekil 2. Ulubey beyaz renkli mermerlerin polarizan mikroskop görüntüleri

(a-b) Ms1 nolu mermer; (c-d) Mc2 nolu mermer; (e-f) Mh3 nolu mermer (Ca: Kalsit, Çt: Çatlak, Op: Opak mineral, Çapraz Nikol (NX) 1000 ve 500 büyütme) 


\section{Tartışma ve Sonuç}

Bu çalışma Ușak İli Ulubey İlçesinde 3 farklı mermer sahasindan moloz boyutlu temin edilen numuneler üzerinde standartlara uygun olarak gerçekleștirilen testler ile mermerlerin fizikomekanik, kimyasal ve mineralojikpetrografik özellikleri belirlenmiștir. Belirlenen bu özellikler TS 1910, TS 2513 ve TS 10449 standartlarında belirlenmiş olan fiziksel ve mekanik özelliklerin sınır değerleri ile karşılaştırılmıştır. Her üç sahadan alınan numunelerin fiziksel özelliklerinin bu çalıșmada karşılaştırması yapılan üç standartta belirtilen sınır değerleri doluluk oranı hariç sağladığı belirlenmiştir. TS 10449 standardına göre doluk oranı minimum \%98 olmalıdır Çalışma bölgesinde yer alan mermerlerin doluluk oranı değerlerinin ise \%93,40-98,35 arasında olduğu hesaplanmıştır. Bölge mermerlerinden Mc2 kodlu mermer doluluk limit değerini sağlarken $(\% 98,35)$, diğer mermerlerin doluluk oranı değerleri standart limitin altında olmakla birlikte bu değere oldukça yakın olduğu görülmektedir. Mermer numunelerinin her üçünün de tüm mekanik özelliklerinin standartlarda değinilen limit değerlerini karşıladığı saptanmıştır.

Mermerlerin kimyasal analiz sonucunda $\mathrm{CaO}$ oranlarının \%51,20-54,00 arasında olduğu, buradan hesapla \%91,43-96,43 oranında kalsit minerali $\left(\mathrm{CaCO}_{3}\right)$ içerdikleri belirlenmiştir. Mermerlere sertlik veren $\mathrm{SiO}_{2}$ oranının $(\% 0,17$ 0,58 arasinda) ve renk veren $\mathrm{Fe}_{2} \mathrm{O}_{3}(\% 0,008$ 0,015 arasinda) ve $\mathrm{TiO}_{2} \quad(\% 0,059-0,076$ arasında) oranlarının oldukça düșük olduğu belirlenmiştir. Saf karbonatlı kayaçların metamorfizması sonucunda beyaz renkli mermerler oluşmaktadır. Beyaz renkli mermerlerin ana bileșeni kalsit mineralleridir. Renk veren ana oksit içeriklerinin düșük olması ve yüksek $\mathrm{CaO}$ içerikleri (>\%51), Ulubey mermerlerinin mermerlerde en çok aranılan renklerin başında gelen beyaz renkli olmalarını sağlamıştır.

Ulubey-Uşak Beyaz mermerlerinde yapılan mineralojik-petrografik incelemelerde tane boyut ölçümlerine göre kalsit minerallerinin tane boyutlarının 147,7 $\mu \mathrm{m}$ ile $3150 \mu \mathrm{m}$ arasında değiştiği ve tane boyut dağılımları açısından ince ve orta taneli mermer sinıfında yer aldıkları belirlenmiştir. İki numunede polisentetik ikizlenmenin çok iyi geliştiği, diğerinde ise ikizlenmenin iyi olduğu belirlenmiștir. Ayrıca iki numunenin alterasyondan fazla etkilenmediği ve tane sınır ilişkilerinin düzgün ve tane sınırlarının belirgin olduğu gözlenirken, diğer numunede yer yer çok düşük derecede alterasyon etkilerine rastlanılmıș ve yer yer opak minerallerinin doldurduğu mikro çatlaklara sahip olduğu belirlenmiștir. Sonuç olarak Ulubey-Uşak beyaz mermerlerinin duvar kaplama taşı, yer döşeme taşı ve doğal yapı taşı olarak kullanılabileceği yapılan çalışmalar neticesinde ortaya konmuştur.

\section{Kaynakça}

[1] DPT, 2001. Madencilik Özel İhtisas Komisyonu Raporu: Endüstriyel Hammaddeler Alt Komisyonu Yapı Malzemeleri II (Mermer-Granit-Yapı TaşlarıArduvaz (sleyt)) Calıșma Grubu Raporu, Sekizinci Beş Yıllık Kalkınma Planı, Yayın No: DPT:2616ÖİK:627, Ankara.

[2] Kalkınma Bakanlığı, 2018. On Birinci Kalkınma Planı (2019-2023) Madencilik Politikaları Özel İhtisas Komisyonu Raporu, Ankara 2018.

[3] Çelik, M.Y., Kırılıveren, S. 2012. Çamlıbel-Ulubey (Usak) Beyaz Mermerinin Jeolojik ve FizikoMekanik Özelliklerinin Araştırılması, Yapı Teknolojileri Elektronik Dergisi, Cilt. 8, No. 1, s. 4453.

[4] Ticaret Bakanlığı, 2020. Doğal Taşlar Sektör Raporu, Ankara.

[5] Özdemir, A.C., Kahraman, E. 2019. Türkiye Madencilik Sektöründe Doğal Taş İhracatının Değerlendirilmesi, Türkiye 10. Uluslararası Mermer ve Doğal Taş Kongresi ve Sergisi, 13-14 Aralık 2019, Bursa/Türkiye.

[6] Zafer Kalkınma Ajansı, 2012. TR33 Bölgesi Mevcut Maden Kaynakları ve Stratejiler, Kütahya.

[7] Aysal, N., ve Korkanç, M. 2002. Sivaslı (Uşak) Mermer Yataklarının Jeolojik ve Mühendislik Özellikleri, İstanbul Üniversitesi Mühendislik Fakültesi Yer Bilimleri Dergisi, Cilt. 15(1), s. 1-10.

[8] Büyüksağiș, İ.S., Gürcan, S. 2005. ASTM ve TSE Doğal Taş Standartlarının Karşılaştırılması, MADENCiLIIK, Cilt. 44, Sayı. 1, s. 33-41, Mart 2005.

[9] TSE, Standart Arama, http:// https://intweb.tse.org.tr/Standard/Standard/Stan dardAra.aspx, (Erişim Tarihi: 10.04.2021).

[10] TS 1910. TSE, Kaplama Olarak Kullanılan Doğal Taşlar, ICS 73.080; 91.100.15, Ankara. (İptal Tarihi: 13.04.2006).

[11] TS 2513. TSE, Doğal Yapı Taşları, ICS 91.100.15, Ankara. (İptal Tarihi: 14.04.2005)

[12] TS 10449. TSE, Mermer-Kalsiyum Karbonat EsaslıYapı ve Kaplama Taşı Olarak Kullanılan, ICS 73.080; 91.100.15, Ankara. (İptal Tarihi: 30.09.2019).

[13] TS 699/T1, 2016. Doğal Yapı Taşları-İnceleme ve Laboratuvar Deney Yöntemleri, ICS 91.100.01; 91.100.15, Ankara.

[14] Onargan, T., Köse, H., Deliormanll, A.H. 2011. Mermer, TMMOB Maden Mühendisleri Odası.

[15] Akçakoca, H., Uysal, Ö., Topal, İ. 2003. Mermerlerin Kalite Kontrol Süreci Açısından Tekno-Mekanik 
Özelliklerinin Önemi, Türkiye IV Mermer Sempozyumu (Mersem 2003) Bildiriler Kitabı, 1819 Aralık 2003.

[16] Moos, A.V., Quervain, F.D. 1948. Technische Gesteinkunde, Verlag Birkhauser, Basel.

[17] Matula, M., Dearman, W.R., Golodkovskaja, G.A Pahi, A., Radbruch-Hall, Dorothy H. 1979. Classification of rocks and soils for engineering geological mapping. Part 1: Rock and soil materials, Bull. Int. Assoc. Engng. Geol, Cilt. 19, s. 364-371.

[18] Deere, D.U., and Miller, R.P. 1966. Engineering Classification and Index Properties for Intact Rock, Air Force Weapons Lab. Tech. Report, AFWLTR-65116, Univ. of Illinois, Urbana.

[19] Bieniawski, Z.T., 1975. The Point-Load Test in Geotechnical Practice. Engineering Geology 9: M p.1.

[20] Atıcı, Ü., 2017. Gümüșler (Niğde) Kalsitinin FizikoMekanik Özelliklerinin Değerlendirilmesi, Ömer Halisdemir Üniversitesi Mühendislik Bilimleri Dergisi, Cilt. 6, Sayı. 1, s. 151-157. DOI: $10.28948 /$ ngumuh.297991

[21] ISRM (International Society for Rock Mechanics), 1981. Rock Characterization, Testing and Monitoring, International Society of Rock Mechanics Suggested Methods, Pergamon Press, Oxford.

[22] Arık, S., Kuşcu, M. 2011. Finike (Antalya) Beydağları Formasyonu'nun Mermer Olarak Kullanılabilirliği ve Ekonomik Önemi, Süleyman Demirel Üniversitesi Fen Bilimleri Enstitüsü, Yüksek Lisans Tezi, Jeoloji Mühendisliği Anabilim Dalı, Isparta

[23] Kun, N. 2000. Mermer Jeolojisi ve Teknolojisi. Tezer Matbaası, s.149, İzmir. 